\title{
Improving Modular Architecture as a Response for Public Schools Emergencies
}

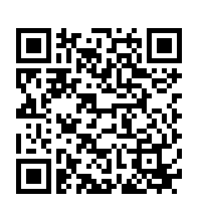

\author{
Pommiez $\mathrm{M}^{1}$, Soto $\mathrm{J}^{2}$, Lara $\mathrm{A}^{1 *}$, Torres $\mathrm{V}^{1}$ and Hempel $\mathrm{C}^{1}$ \\ ${ }^{1}$ Department of Architecture, University of Concepción, Chile \\ ${ }^{2}$ Independent architect consulting, University of Concepción, Chile
}

Submission: June 21, 2021; Published: July 01, 2021

*Corresponding author: Lara A, Department of Architecture, University of Concepción, Chile

Abstract

This research analyzes the modular architecture solution (container prototype) implemented by the Chilean government after the tsunami earthquake of February 27 [1], to replace critical infrastructure lost (school), focusing on the classroom's habitability and environmental comfort concept. A mixture investigation was carried out through a documentary analysis that examines the legal requirements with the proposal implemented and modelling and calculation of the variables that make up the passive architecture of the envelope, with the current legal terms of reference. The results indicate the existing habitability gaps in terms of space, air quality and overheating and the need to promote adaptations oriented to the change of paradigm from emergency to resilient architecture.

Keywords: Modular architecture; Container; Critical infrastructure; Risk management; Public education

\section{Background}

During this new millennium, disasters have affected 4.4 billion people, casualties more than 1.3 million, destroyed invaluable ecosystems, and caused USD 2 trillion losses [2]. Earthquake, flood, tsunami, wildfire, health emergencies or pandemics affected worldwide; however, developing countries are the most vulnerable places globally. They do not know or capacities to effectively face and manage these extreme events [3]. In this context, critical infrastructure (school and hospital) located in a prone risk zone or built under nonresistance criteria suffered significant damages [4], transforming into substantial economic and social losses for these countries. The international community understands education as the fundamental topic for developing peoples and territories and improving resilience capacities for managing disasters [5-7]. The Sendai framework emphasizes considerably reducing the damage caused by disasters in vital infrastructures such as education, where built back better in the recovery cycle, rehabilitation and reconstruction is a priority to be fulfilled by the year 2030 [8].

In this sense, the Architectural response to a catastrophic situation must offer sufficient flexibility to satisfy priorities and needs. It must also take care of the geographical particularities and environmental elements [9-12]. For example, the Earthquake and Tsunami that affected Chile on February 27 [1] imposed a great challenge on the reconstruction process to replace the lost educational infrastructure [13]. Because to have a quality educational infrastructure is a primary country common goal related to improving academic results and imperative to train future generations in a welcoming environment to develop happiness. [14].

Here, the concept of habitability from the vision of a progressive architecture of the educational space goes beyond an emergency approach, becoming a significant field. According to Jiron et al. [15], "habitability is determined by the relationship and adequacy between the person and their environment. Moreover, it refers to how each territorial scale has evaluated according to its ability to satisfy human needs. This concept is related to the fulfilment of minimum standards since habitability is the quality of habitable, particularly that according to certain legal norms, premises, or home has". In this sense, we conceptualize habitability as the ability of a building to ensure minimum conditions of comfort and health for its inhabitants [16]. Furthermore, in a context of a constant increase in energy demand, progressive Greenhouse Gas 


\section{Civil Engineering Research Journal}

(GHG) emissions and deepening of the consequences of climate change [3]. Therefore, responses from the passive architectural design of educational spaces are in high demand to ensure sustainability and proper buildings functioning $[9,17]$.

Understanding how urgent and relevant the replacement of post-disaster school is, the so-called Container Architecture as a modular system appears as a suitable alternative to implement. According to Kotnik [18], this typology can offer a wide range of spatial solutions, in addition to rapid materialization, low cost, freedom in design expression and useful life of 7 to 14 years. Modular schools architecture has defined as portable classrooms that provide flexibility to balance the needs of classrooms and supply spaces for community use [19]. Due to its characteristics, the container conforms to the principles of firmness, durability and utility that give it an infinite potential for solutions and interpretations for the architect [20]. While modular schools have designed to be aesthetically beautiful and functionally modern [21], their initial design process is not intended as part of a developing evolutionary cycle $[22,23]$. The one that exceeds the time of use above its useful life requires a continued capacity for adaptability to extreme changes, which allow it to guarantee the minimum conditions for life in terms of energy efficiency [24]. Within the mail goal of robustness, the resilience capacity of the modular school. This research aims to analyze passive architectural design strategies of a modular classroom prototype to verify the environmental comfort conditions according to Geographical Zones of Chile and Types of Buildings, modelling and calculation data from the Standardized Terms of Reference of the Ministry of Public Works (TDRe MOP).

\section{Case of Study}

\section{Context and climate zone identification}

Iloca, Licantén Commune Maule region (Figure 1), was one of the most affected towns by the earthquake and tsunami of February 27, [1] on the Chilean coast. The impact was severe, causing destroyed infrastructure, urban equipment, water scarcity, power outages, the collapse of the communication system, fear and insecurity [1]. According to NCh 1079 Of. 2008 the town of Iloca is on Latitude $34^{\circ} 55^{\prime}$ South and Longitude $72^{\circ} 10^{\prime}$ West, in the climatic zone Zone $4 \mathrm{CI}$ (zone 4 central interior), penetrating widely in the broad valleys that open the mouths of the rivers. It is an area with a maritime climate; this is short winters of four to six months, mild temperature, cloudiness in summer dissipated at noon, high and medium rainfall increasing towards the South with predominant SW components, soil, and saline environment humid. Due to the non-existence monitoring stations in Licantén and Iloca, information has extracted from the AccuWeather site. Therefore, the temperature graphs of the coldest month (July) and the warmest month (January) correspond to 2020. The temperature graphs show that in January, the average of the daily maximum temperatures exceeds $28^{\circ} \mathrm{C}$ and the standard of the minimums is above $12^{\circ} \mathrm{C}$. On the other hand, the average daily maximum temperatures are below $14^{\circ} \mathrm{C}$ in July, and the average minimum is around $2{ }^{\circ} \mathrm{C}$. The above generated a solid seasonal thermal oscillation with a sweltering summer and a cold winter.

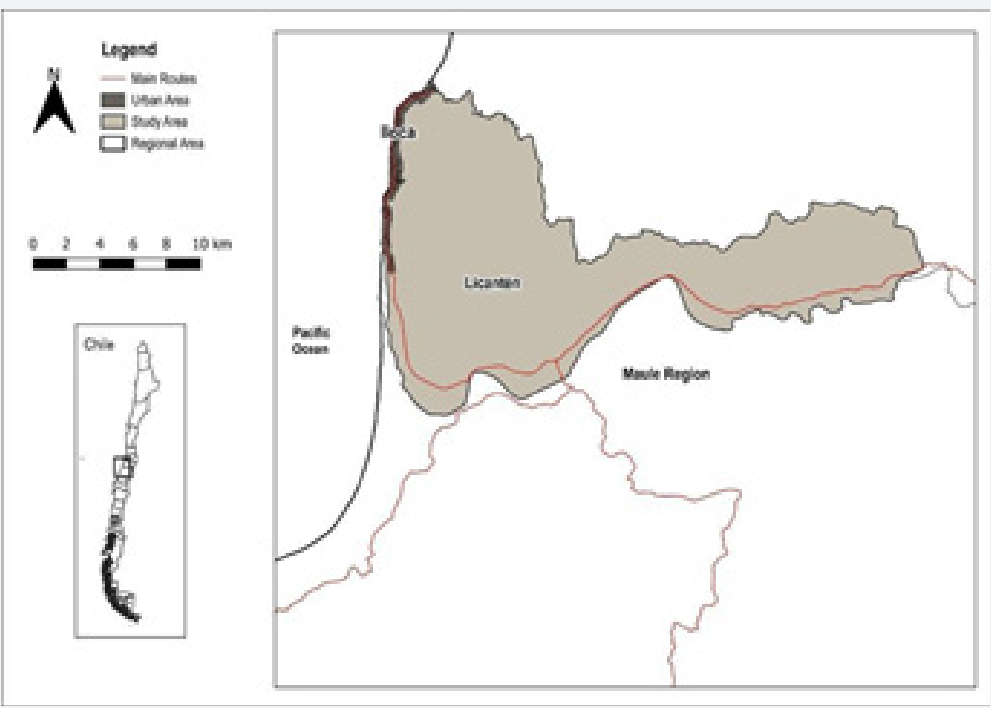

Figure 1: Location map. Source: developed by Cristobal Palma.

\section{Modular emergency school prototype}

After evaluating various construction alternatives and their applicability in school campuses, a Modular System was chosen, which met the quality requirements, delivery times and volumes required to cope with the emergency [25]. The selected modules, mainly from the United States, offered multiple advantages 


\section{Civil Engineering Research Journal}

concerning transportation and assembly time. They were fully armed units, clad on the outside with steel and aluminium plate, whose upright system facilitated transport by land. The construction of these emergency schools to project three essential elements: modular rooms, covered steps and sheds to protect the multipurpose fields (in some cases), gardens and playgrounds are also incorporated. The contribution of the architectural design consisted of the spatial organization, the functional arrangement and the conformation of fills and voids to create an environment conducive to education, which in many cases surpasses the original enclosures.

The Chilean Regulation, Supreme Decree 548 in Articles 11 and 12 , grants these emergency schools to consider the norms related to the conditions of capacity, health and hygiene for the enrollment to attend and is given a maximum term of five years to comply with the requirement entirely [26]. Furthermore, around $60 \%$ of these emergency schools are still standing today, although 11 years have passed in their construction. However, they have deficiencies in the quality efficiency-energy and waterproofing of the modules considering the repeated use by the school community [27]. The Modular Emergency School Iloca has taken as a reference. This new emergency construction, manufactured by the Tecno Fast company, housed 200 students between 1st and 8th grade in a $300 \mathrm{~m} 2$ school, being the first of 320 modular emergency schools built in Chile by the "Schools for Chile" foundation (Table 1). A Modular school has built in just 20 days between the earthquake and its inauguration. Its rapid management and construction allowed the classes without delay. The school has six classrooms, bathrooms, a computer, a teacher, and a dining room designed to consider thermal insulation and energy efficiency (Figures 2-5). The module structures have made of steel and wood, manufactured and transported, finished to their destination and those that come fully equipped from the factory. The Research emphasis is placed on the classroom (Figure 6), as it is the venue where students do the most activities and spend most of the time; that is why its correct conception is vital when running a modular emergency school. Classrooms have intrinsic advantages in modular construction, as is the versatility and flexibility. Two modules of $2.5 \times 6$ meters have used for their construction, where they intended for a maximum of 25 students per classroom.

Table 1: Illoca school general summary.

\begin{tabular}{|c|c|c|c|c|}
\hline Construction Year & Company & Level & Capacity & Size \\
\hline $2010-2014$ & Anglo American -Tecnofast & Primary School & 200 students & 341 M2 \\
\hline
\end{tabular}

Source: developed by the author.

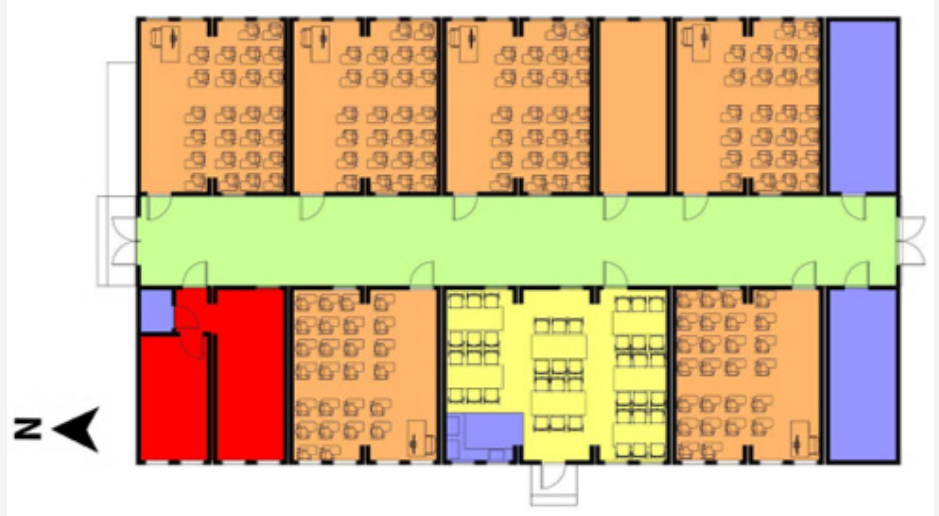

Administration Wet Zone $\quad$ Classroom

\section{School Cafeteria $\square$ Circulation}

Figure 2: Floor Illoca school.

Source: developed by the authors from the original project Tecnofast, 2010.

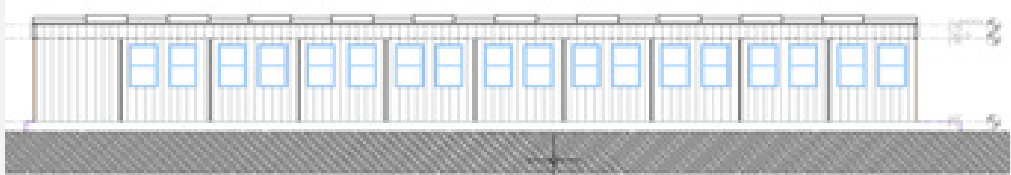

Figure 3: East elevation Illoca school.

Source: developed by the authors from the original project Tecnofast, 2010. 


\section{Civil Engineering Research Journal}

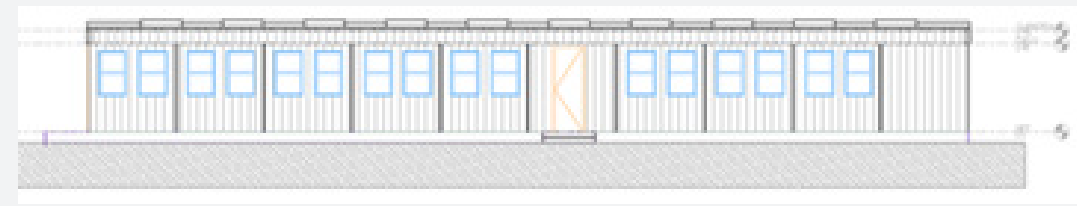

Figure 4: West elevation Illoca school.

Source: developed by the authors from the original project Tecnofast, 2010.

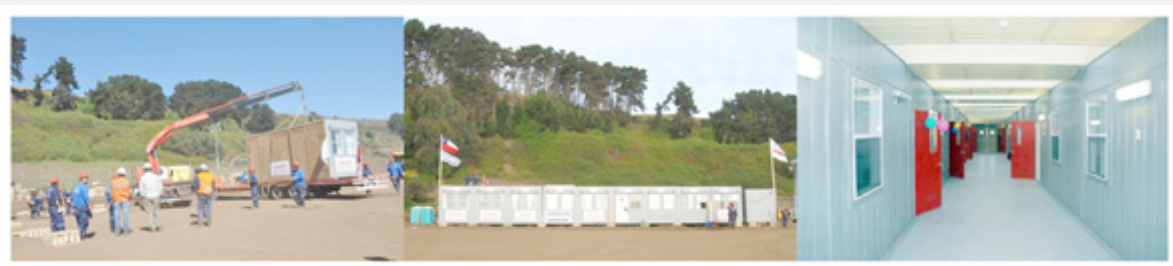

Figure 5: Modular Illoca School, the installation process.

Source: Plataforma Arquitectura [38], developed by the authors from the original project Tecnofast, 2010.

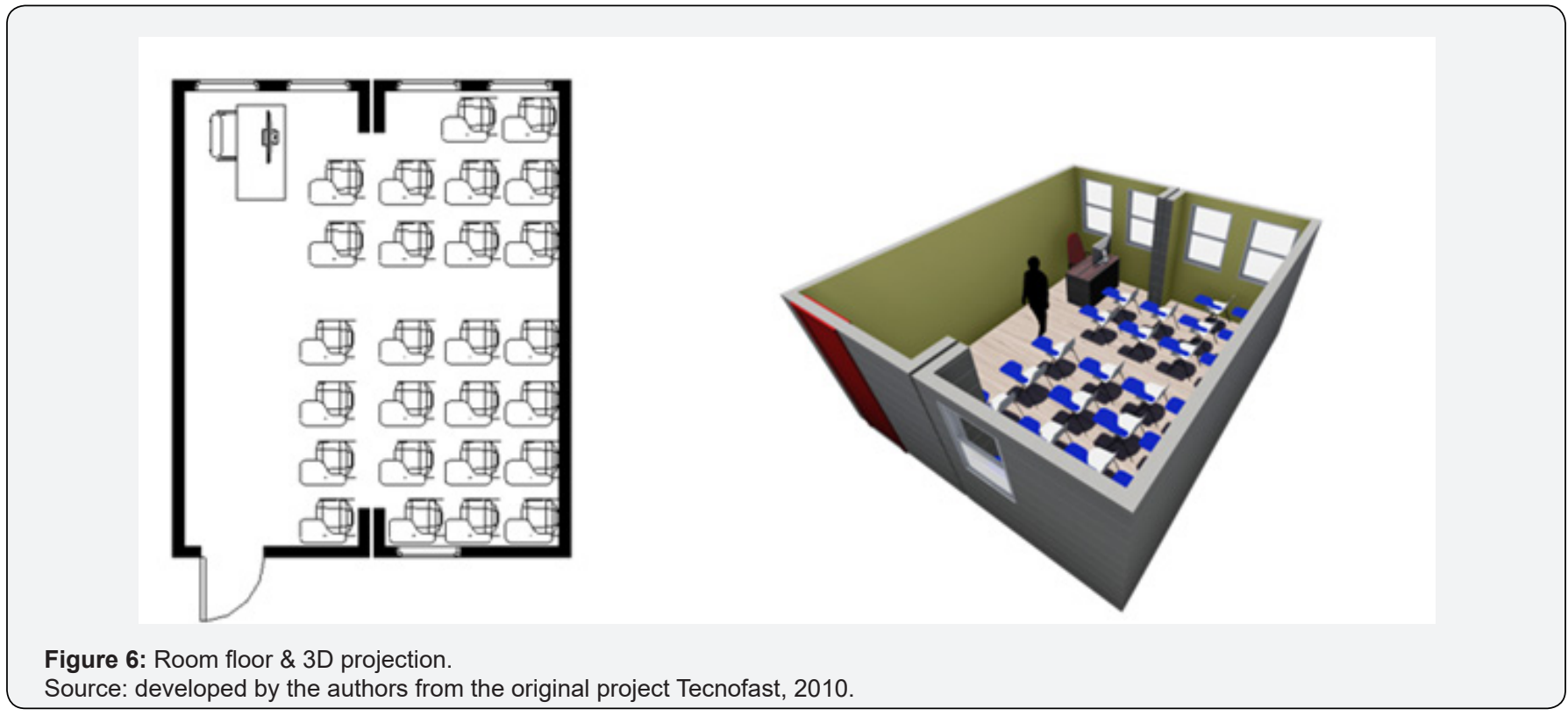

Source: developed by the authors from the original project Tecnofast, 2010.

The main design criteria used in the classroom includes a height from floor to ceiling of $2400 \mathrm{~mm}$, structured to withstand an overload of $200 \mathrm{~kg} / \mathrm{m} 2$. The foundations have made of pine wood supports. The idea is to transfer the loads to the ground with maximum contact stress of $1.45 \mathrm{Kg} / \mathrm{cm} 3$; it is considered 2.0 $\mathrm{kg} / \mathrm{cm}$ in the case of seismic stresses. The structuring o comprises radiata pine wood considering a $90 \mathrm{~mm}$ thick floor (walls and ceiling structure). The interior floor finish liner is $1.5 \mathrm{~mm}$ wide vinyl flooring, laid over the polished surface. The exterior wall cladding has considered siding in wood type smart panels of $7 / 16$ ", with a synthetic oil painted finish. At the same time, the walls considered in the interior plasterboard RF (fire resistance) of $15 \mathrm{~mm}$ thickness, covered with $9 \mathrm{~mm}$ thick grooved decorative phenolic plywood sheet, with paint finish. The roof has a $1.2 \mathrm{~mm}$ PVC membrane covered on the outside, which receives the OSB plate, and the ceiling finishes with $15 \mathrm{~mm} \mathrm{RF}$ cardboard plaster, wallpaper with vinyl mural paper. Moreover, the classrooms consider a wooden door peephole with double pane windows; thermo-enamelled aluminium frame vertical sliding with $815 \times 1215 \mathrm{~mm}$ thermopanel glass; five windows to achieve air circulation, considering that the orientation of these classrooms is East-West.

\section{Methodology}

A diagnosis of the current project will be carried out, based on the TDRe MOP standards, to verify its capacities to limit energy demand and promote energy efficiency in its thermal facilities. The variables considered for this research are the Climate zone (limit values for climate zone) and passive design strategies (orientation, heating, cooling, natural ventilation) (Table 2). A systematic summary of the research methodology is present 


\section{Civil Engineering Research Journal}

in (Figure 7). Second, the natural ventilation capacity will be analyzed, under current normative parameters contained in the General Urban Planning and Construction Ordinance, article 4.5.6, in such a way as to comply with the adequate air quality for the

Table 2: Variable and consideration for diagnosis analysis.

\begin{tabular}{|c|c|}
\hline Variable & Consideration \\
\hline $\begin{array}{l}\text { 1. Climatic Zone (Independent } \\
\text { Zone) }\end{array}$ & $\begin{array}{l}\text { Identification of the climatic zone according to the Chilean Norm (NCh } 1079 \text { Of. 2008) and the climatic data of } \\
\text { the place }\end{array}$ \\
\hline $\begin{array}{l}\text { 1.1. Analysis Limit values for } \\
\text { Climatic Zone }\end{array}$ & $\begin{array}{l}\text { Thermal transmittance } \mathrm{U} \text { : heat flow that passess per unit surface area of the element and degree of the } \\
\text { temperature difference betwwen the two environments seperated by said element. (NCh } 853 \text { Of. 2007) it is } \\
\text { expressed in } \mathrm{W} /\left(\mathrm{m}^{2} \mathrm{xk}\right) \text { and calculated } 853 \text { Of. } 2007 \text {. The limit thermal trnasmittance must be read as the maxi- } \\
\text { mum value that the construction solution must-have. Thus, the U-values obtained must be equal to or less than } \\
\text { the limit values set in the comparison instrument (TDRe MOP) }\end{array}$ \\
\hline $\begin{array}{l}\text { 2. Analysis of passive design strat- } \\
\text { egies (Dependent variable) }\end{array}$ & $\begin{array}{l}\text { We have focused on an envelope with characteristics that adequately limit the energy demand to satisfy the } \\
\text { thermal comfort requirements of the living spaces, in this case, the classroom. }\end{array}$ \\
\hline 2.1. Orientation & $\begin{array}{l}\text { The orientation of buildings largely determines the energy demand for heating and cooling of the building in } \\
\text { the future. Good guidance could considerably minimize energy demands by controlling solar gains. (TDFe_ } \\
\text { MOP-DA_PART1) }\end{array}$ \\
\hline 2.2. Passive heating strategies & $\begin{array}{l}\text { Winter strategies have aimed at passive heating of spaces. Still it is crucial to discriminate whether the climatic } \\
\text { and use characteristics of the building result in these strategies being relevant (TDRe_MOP-DA_PART1) }\end{array}$ \\
\hline 2.3. Passive cooling strategies & $\begin{array}{l}\text { Summer strategies have aimed at passive cooling of spaces through adequate solar protection that considers } \\
\text { the different orientations of the enclosures, natural ventilation and passive evaporative cooling in those cases } \\
\text { where the local climate allow it (TDRe_MOP-DA_PART1) }\end{array}$ \\
\hline 2.4. Natural ventilation strategies & $\begin{array}{l}\text { Ventilation strategies should be considered for winter and summer, aiming to ensure the indoor air quality in } \\
\text { winter. At the same time, in summer, it must also provide the thermal comfort of its occupants. (TDRe_MOP-DA- } \\
\text { PART1) }\end{array}$ \\
\hline
\end{tabular}

Source: developed by the authors.

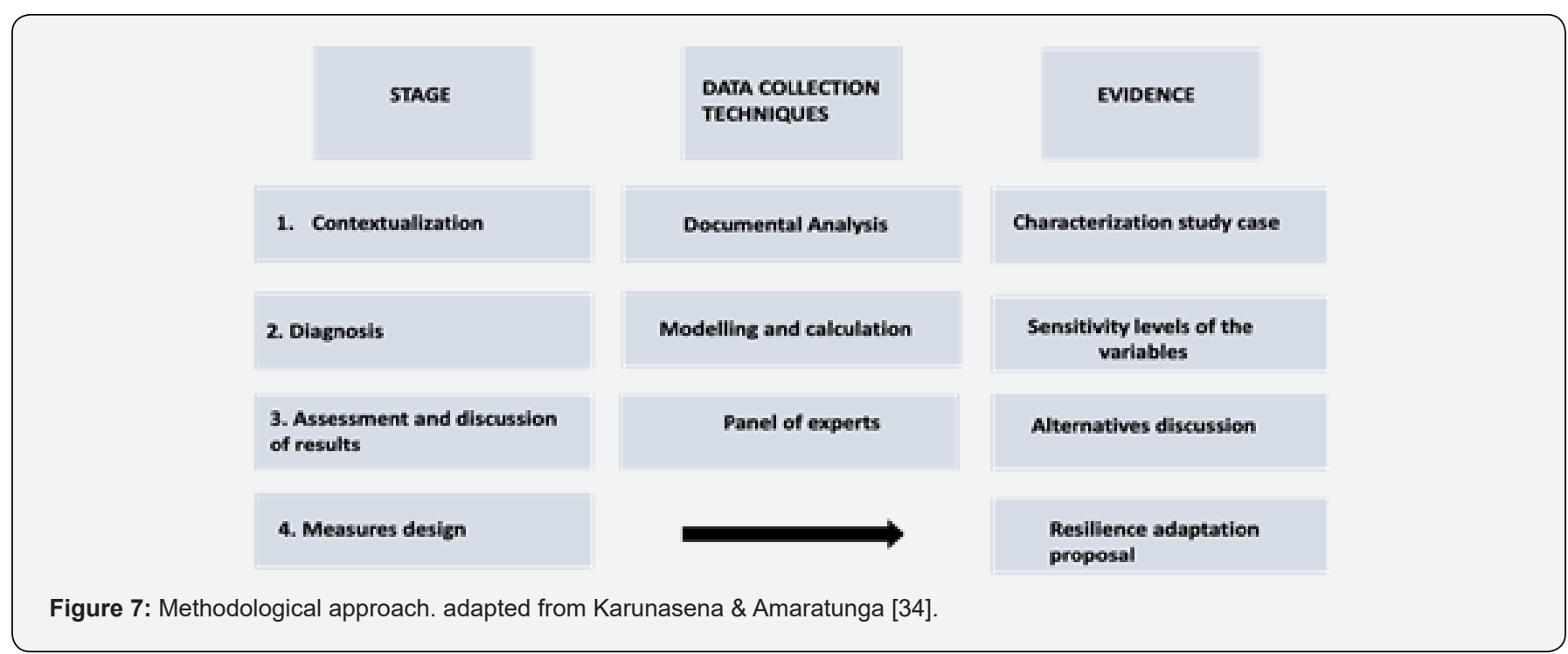

\section{Results}

Passive design strategy analysis: It has estimated that, between the ages of 4 and 17, people spend at least $70 \%$ time in a school classroom. Starting from this base, providing a healthy premises school classrooms with their climate zone. Third, an expert panel of architects meets to analyze the results, which test different alternatives to reach an optimal level of the dependent variables studied concerning the climatic zone. 


\section{Civil Engineering Research Journal}

of this building is essential, especially when in a catastrophe situation, the power supplies have cut off, and the building must function with maximum autonomy. The passive strategies to analyze are:

\section{Orientation}

Figure 8: Solar path.

Source: developed by the authors
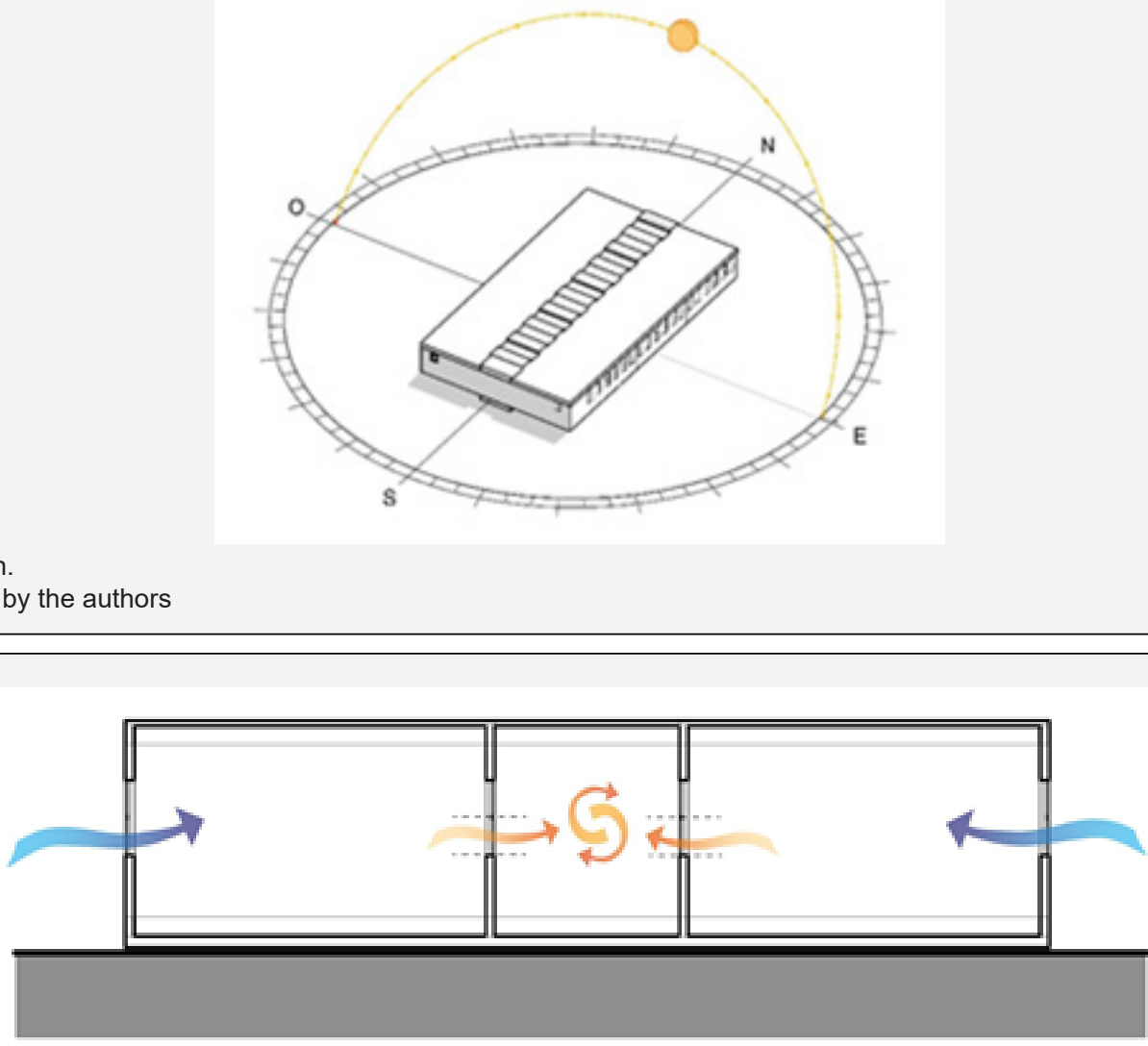

Figure 9: Passive cooling.

Source: developed by the authors.

The orientation of the classrooms should ideally be northsouth since there is greater control of solar radiation through an eave on the north façade (Figure 8). At the same time and due to the solar inclination, no damping will occur. However, as shown in (Figure 9), the orientation of the school is east-west. This location can cause glare and overheat, especially on the western side.
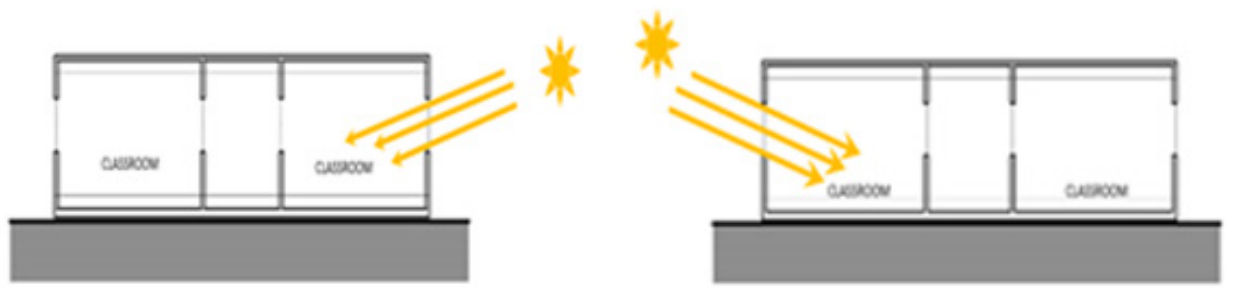

Figure 10: Left: Morning passive heating. Right: Afternoon passive heating.

Source: developed by the authors.

Passive heating strategies: Due to the east-west orientation (Figure 10), the passive heating strategy of this school is deficient since, during the winter, there are very few hours of sunlight on these facades. To this must be added the overheating that occurs predominantly on the west facade in the summer period. In summary, passive heating does not take place adequately in 


\section{Civil Engineering Research Journal}

winter. Furthermore, overheating is also generated in summer since the windows do not have sun protection and have no solar absorption coefficient.

Passive cooling strategies: In general, passive cooling systems are recommended mainly in public buildings located in the climatic zones 1-Norte Litoral, 2-Norte Desértico, 3-Norte Valles Transversal, 4- Litoral Center and 5-Interior Center, which correspond to climatic zones characterized by their high temperatures in summer. (Manual de Diseño Pasivo y Eficiencia Energética en Edificios Públicos p.77). Such is the case of this school that belongs to zone 4 litoral centre. This school does not have either two cooling system forms (natural ventilation or passive strategy). No cross ventilation allows the classroom to cool down since the air has trapped in the corridor of the building, as shown in (Figure 9).

Natural ventilation strategies: There are 4 operable windows for air intake in each classroom. However, the air outlet has reduced since one window per room. In addition, the air tends to be trapped in the corridor, as shown in (Figures $11 \& 12$ ). It does not have mechanical systems of ventilation. Therefore, the only possibility of air exchange is through natural ventilation. This problem represents the renewal of air is essential to control carbon dioxide levels, humidity, and pollutants in suspension present in the interior spaces.

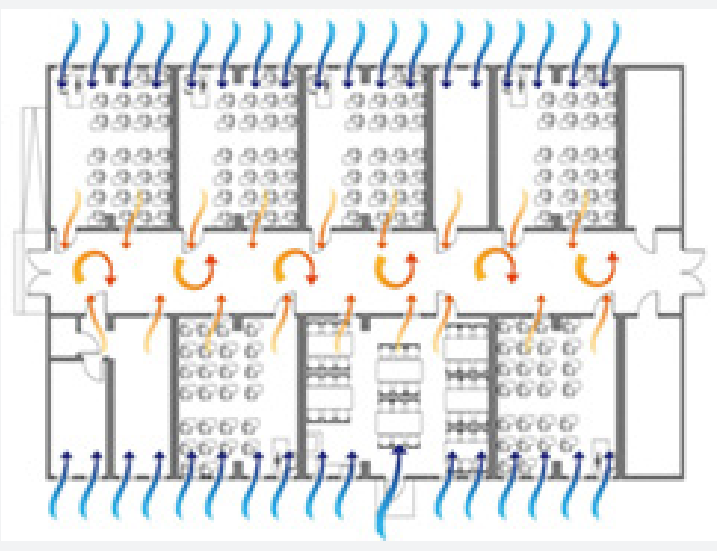

Figure 11: Scheme of natural ventilation situation (1).

Source: developed by the authors.

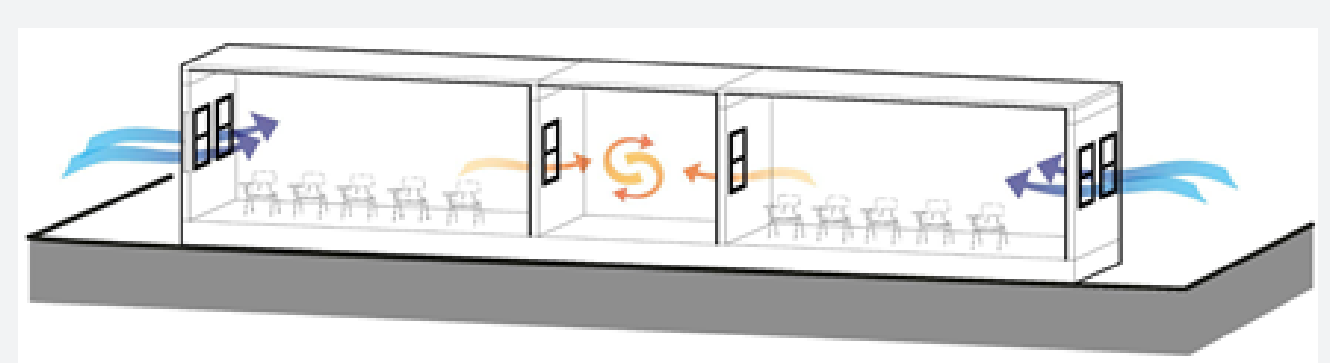

Figure 12: Scheme of natural ventilation situation (2).

Source: developed by the authors.

\section{Analysis limit U values for climate zone Z 4CL:}

To check the limit values of thermal transmittance of the envelope, we proceed to the thermal calculation of each element (Roof, wall and ventilated floor) under the calculation standard of NCh 853 Of. 2007.

$$
R_{T}=\frac{1}{U}=R_{s i}+\sum \frac{e}{\lambda}+R_{s e}
$$

Where:

$R_{T}=$ Total thermal resistance $\left(\mathrm{m}^{\wedge} 2 \times \mathrm{k}\right) / \mathrm{W}$

$\sum \frac{e}{\lambda}=$ Summation of the thermal resistances of the layers that make up the element

$R_{s i}=$ Interior surface resistance 


\section{Civil Engineering Research Journal}

$R_{s e}=$ Exterior surface resistance

$U=$ Thermal transmittance $\mathrm{W} /\left(\mathrm{m}^{\wedge} 2 \times \mathrm{k}\right)$

$$
\bar{U}=\frac{1}{R_{T}}=\frac{\sum U_{i} \times A_{i}}{\sum A_{i}}
$$

$A_{i}=$ mean thermal transmittance

$\bar{U}=$ the surface of the part of the element to which a thermal

\section{transmittance Ui corresponds}

For climatic zone 4 Central Litoral, the values of maximum thermal transmittance for the envelope (U) are the following: Roof limit 0,6, Wall 0,8, Ventilated floor 1,2.

Constructive description: It is a pavilion on one floor consisting of 21 transportable modular units. Each modular unit is factory assembled, placed on a wooden foundation. Its envelope is composed as follows

Table 3: Values of maximum thermal transmittance for envelope $(U)$, climatic zone 4 Central Litoral.

\begin{tabular}{|c|c|}
\hline Roof & $1.2 \mathrm{~mm}$ thick PVC membrane cover \\
\hline Cover & $15 \mathrm{~mm}$ OSB exterior, glued and bracketed \\
\hline Beams & Pine radiata $42 \times 140$ every $406 \mathrm{~mm}$ e/e \\
\hline Truss & Radiata pine $42 \times 90$ to $42 \times 0 \mathrm{~mm}$ every $600 \mathrm{~mm}$ e/e, to provide roof slope \\
\hline Insulation & $90 \mathrm{~mm}$ thick fiberglass \\
\hline Vapour barrier & polyethene thickness $0.15 \mathrm{~mm}$ \\
\hline Finish & $15 \mathrm{~mm}$ plasterboard, RF type, pre-wrapped with the paper vinyl mural, white \\
\hline
\end{tabular}

Source: developed by the authors.
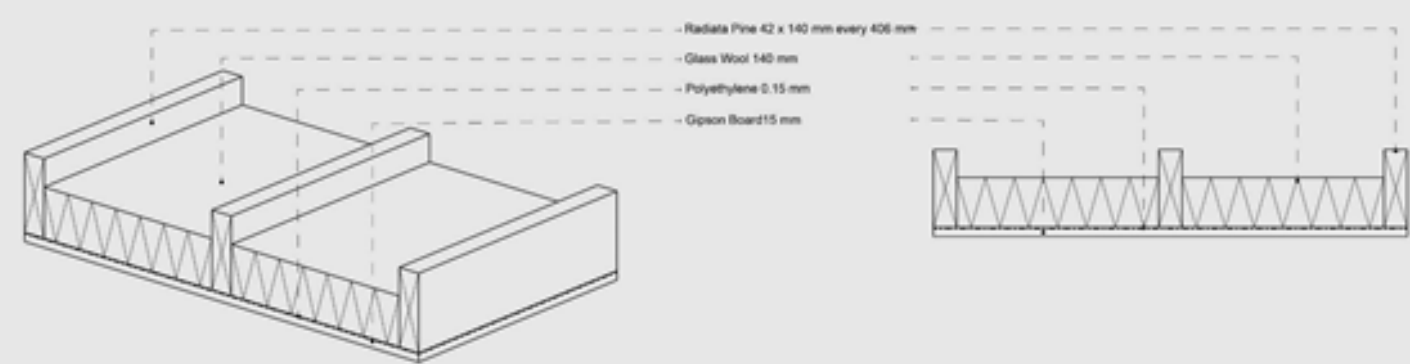

Figure 13: Construction detail of the placement of thermal insulation on the roof (Thermal insulation is interrupted by roof beams). Source: developed by the authors.

Table 4: The result from roofing thermal transmittance.

\begin{tabular}{|c|c|c|}
\hline Items & Iloca School U Value $\mathbf{w} /\left(\mathbf{m}^{2} \mathbf{k}\right)$ & Zone $\mathbf{4}$ CL U Value w/(m $\left.{ }^{2} \mathbf{k}\right)$ \\
\hline Roof limit transmittance & 0,47 & 0,6 \\
\hline
\end{tabular}

Source: developed by the authors.

Table 5: Technical specification of the wall.

\begin{tabular}{|c|c|}
\hline Exterior finish & $\begin{array}{c}\text { Siding cladding in wood type Smart Panel 7/6" (11.1mm) from Louisiana Pacific, with two hands of semi- } \\
\text { gloss synthetic oil finish }\end{array}$ \\
\hline Cover & $9.5 \mathrm{~mm}$ OSB exterior \\
\hline Stud and top\&bottom plate & $42 \mathrm{~mm}$ x $90 \mathrm{~mm}$ radiant pine $\mathrm{H}=12 \%$, each $406 \mathrm{~mm}$ e e. \\
\hline Insulation & $90 \mathrm{~mm}$ thick fiberglass \\
\hline Vapour barrier & polythene thickness $0.15 \mathrm{~mm}$ \\
\hline Top finish & 15mm plasterboard, RF type, pre-wrapped with the paper vinyl mural \\
\hline Lower cladding up to 1.20 meters & A decorative phenolic plywood sheets, 9 mm slotted of thickness \\
\hline
\end{tabular}

Source: developed by the authors. 


\section{Civil Engineering Research Journal}

Roof: the construction solution has made up from the outside to the inside (Table 3). (Figure 13) indicated the placement of the thermal insulation. The result (Table 4) is that the thermal transmittance of the school roof is below the limit value required for the 4CL climatic zone, according to the TDRe MOP standard.

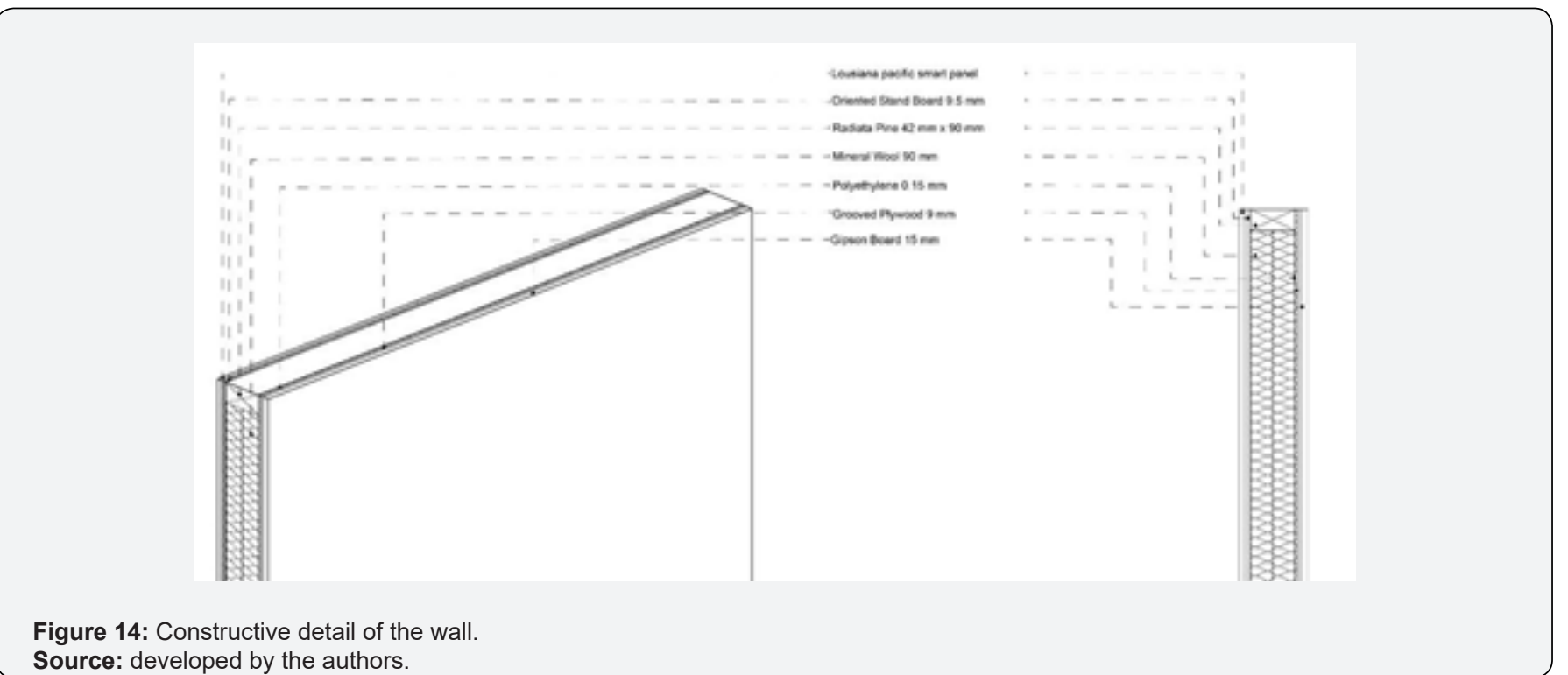

Wall: the construction solution has made up from the outside to the inside (Table 5). (Figure 14) indicated the placement of the thermal insulation. The panel is composed only of stud and plate, (Table 6) is that the school's thermal transmittance was below the limit value required for the 4CL climatic zone, according to the and the thermal insulation goes between the studs. The result

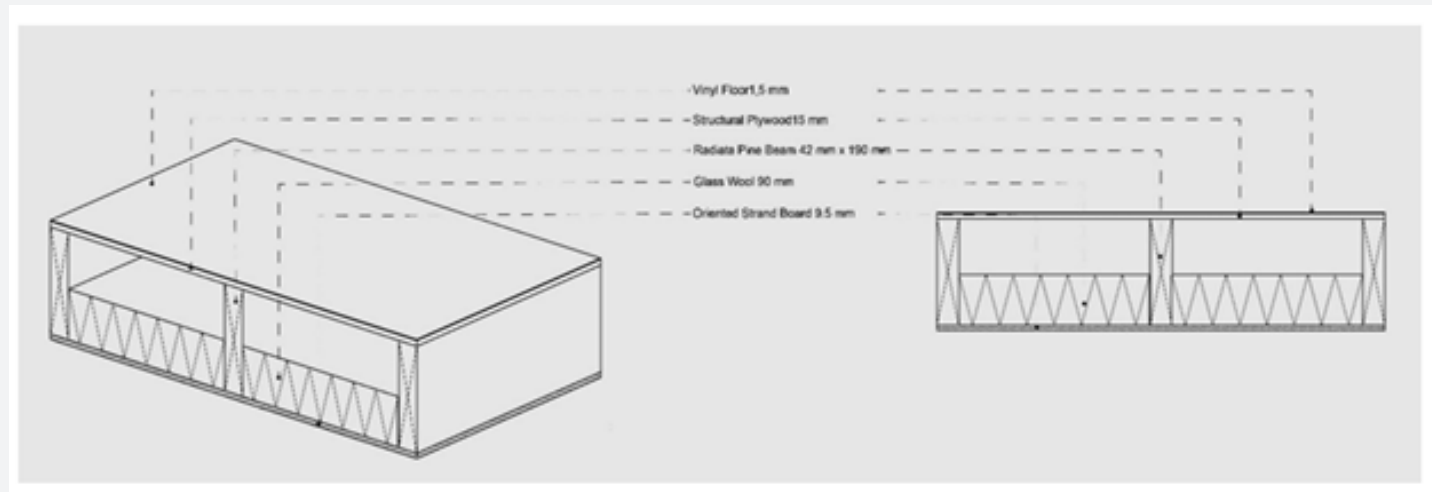

Figure 15: Constructive detail of the ventilated floor. Thermal insulation is interrupted by floor beams.

Source: developed by the authors.

Table 6: Result thermal transmittance of the wall.

\begin{tabular}{|c|c|c|}
\hline Items & Iloca School U Value $\mathbf{w} /\left(\mathbf{m}^{2} \mathbf{k}\right)$ & Zone $\mathbf{4}$ CL U Value $\mathbf{~} /\left(\mathbf{m}^{2} \mathbf{k}\right)$ \\
\hline Wall limit transmittance & 0,48 & 0,8 \\
\hline
\end{tabular}

Source: developed by the authors.

Table 7: Technical specification of the ventilated floor.

\begin{tabular}{|c|c|}
\hline Cover & $15 \mathrm{~mm}$ OSB exterior, glued and bracketed \\
\hline Floor Beams & $42 \mathrm{~mm} \times 190 \mathrm{~mm}$ Pine Radiata $\mathrm{H}=12 \%$ with fasteners of beams every $406 \mathrm{~mm}$ e/e \\
\hline Insulation & $90 \mathrm{~mm}$ thick fiberglass \\
\hline Floor & $15 \mathrm{~mm}$ structural plywood, glued and screwed \\
\hline Floor covering & Vinyl siding in roll $1.5 \mathrm{~mm}$ thick. It Placed on the polished surface \\
\hline
\end{tabular}

Source: developed by the authors. 


\section{Civil Engineering Research Journal}

Ventilated floor: the construction solution has made up from the outside to the inside (Table 7). (Figure 15) indicated the placement of the thermal insulation.

The result (Table 8) is that the thermal transmittance of the school wall is below the limit value required for the 4CL climatic zone, according to the TDRe MOP standard. In summary, the thermal transmittance of the envelope complies with all the limit values of zone 4 Central Litoral. Regarding the rest of the climatic zones of Chile, the result is the following (Table 9). According to (Table 9), the school understudy's constructive solution is fully compliant in 3 of the 9 climate zones (33\%). We can also observe that:

Table 8: Result thermal transmittance of the ventilated floor.

\begin{tabular}{|c|c|c|}
\hline Variable & Iloca School U Value w/(m $\left.\mathbf{m}^{\mathbf{k}} \mathbf{k}\right)$ & Zone 4 CL U Value w/(m $\left.{ }^{\mathbf{2}} \mathbf{k}\right)$ \\
\hline Ventilated floor limit transmittance & 0,39 & 1,2 \\
\hline
\end{tabular}

\section{Source: developed by the authors.}

Table 9: Comparative table of results for the nine climatic zones of Chile.

\begin{tabular}{|c|c|c|c|c|c|c|c|c|c|c|c|}
\hline \multirow[t]{2}{*}{ Variable } & $\begin{array}{l}\text { Iloca } \\
\text { School }\end{array}$ & $\begin{array}{l}\text { Zone } \\
\text { 4CL }\end{array}$ & $\begin{array}{l}\text { Zone } \\
1 \mathrm{NL}\end{array}$ & $\begin{array}{l}\text { Zone } \\
\text { 2ND }\end{array}$ & $\begin{array}{l}\text { Zone } \\
\text { 3NVT }\end{array}$ & $\begin{array}{l}\text { Zone } \\
5 \text { CL }\end{array}$ & $\begin{array}{l}\text { Zone } \\
6 S L\end{array}$ & $\begin{array}{l}\text { Zone } \\
\text { 8SE }\end{array}$ & $\begin{array}{c}\text { Zone } \\
\text { 7SI }\end{array}$ & $\begin{array}{l}\text { Zone } \\
\text { 9AN }\end{array}$ & \multirow[t]{2}{*}{ Compilance } \\
\hline & \multicolumn{10}{|c|}{$\mathrm{U}$ value $\mathrm{w}\left(\mathrm{m}^{2} \mathbf{k}\right)$} & \\
\hline $\begin{array}{l}\text { Roof limit transmit- } \\
\text { tance }\end{array}$ & 0,47 & 0,6 & 0,8 & 0,4 & 0,6 & 0,4 & 0,4 & 0,3 & 0,25 & 0,25 & \multirow{3}{*}{$33 \%$} \\
\hline $\begin{array}{l}\text { Wall limit transmit- } \\
\text { tance }\end{array}$ & 0,48 & 0,8 & 2 & 0,5 & 0,8 & 0,6 & 0,6 & 0,5 & 0,4 & 0,3 & \\
\hline $\begin{array}{l}\text { Ventilated floor limit } \\
\text { transmittance }\end{array}$ & 0,39 & 1,2 & 3 & 0,7 & 1,2 & 0,8 & 0,8 & 0,7 & 0,5 & 0,4 & \\
\hline
\end{tabular}

Source: developed by the authors.

I. The construction system fully complies with the site climate zone Z 4CL, Z 1NL and Z 3NVT (33\%)

II. The original thermal solution does not discriminate the amount of thermal insulation for each enclosure element; it is $90 \mathrm{~mm}$ of glass wool in walls, ventilated floors and roofs, which causes over-dimensioning, especially in walls and ventilated floors.

Table 10: Student area, volume and capacity values (artíc. 4.5.6).
III. The ratio of area and volume of air appropriate to students' capacity (Artículo 4.5.6 OGUC, (Tables 10-12)): To ensure an adequate air volume for the student capacity. Activity rooms, classrooms, workshops, laboratories, and libraries must meet the standards indicated in the following table: Therefore, the relation between area and volume for adequate air for each student is deficient, considering 25 students for these classrooms.

\begin{tabular}{|c|c|c|c|}
\hline Parameters & Air Volume M3/ Student & Classroom and Activity Room Surface & Surface Workshops $\mathbf{m}^{2} /$ Student \\
\hline Required & 3 & 1.1 & 1.5 \\
\hline
\end{tabular}

Source: developed by the authors.

Table 11: Classroom dimensions.

\begin{tabular}{|c|c|}
\hline Classroom Surface (6) & $27 \mathrm{~m}^{2}$ \\
\hline Classroom Height (roof to ceiling) & $2,40 \mathrm{~m}$ \\
\hline Number of students per classroom & 25 \\
\hline
\end{tabular}

Source: developed by the authors.

Table 12: Relation among legal framework and case of study in terms of adequate air volume.

\begin{tabular}{|c|c|c|c|}
\hline Parameters & Air Volume M3/ student & Classroom and activity room surface & Surface workshops $\mathbf{m}^{2} / \mathbf{s t u d e n t}^{-1.1}$ \\
\hline Required & 3 & 1.08 & 1.5 \\
\hline Case of Study & 2.59 & 0.52 \\
\hline
\end{tabular}

Source: developed by the authors.

\section{Discussion and Proposal}

Currently, Chile does not have expedited access to financing for architecture projects in critical infrastructure before a catastrophe. Only at the time of the emergency, public funds allocated; therefore, there is no prevention building-architectural prevention against a crisis [9]. The incorporation of passive 


\section{Civil Engineering Research Journal}

architectural design strategies to achieve environmental comfort conditions (hygrothermal, visual, acoustic and air quality) demanding a minimum of energy according to the local climatic characteristics of the school [28]. The prefabrication of modular elements allows structural construction and fully integrated construction elements; thermally insulated panels, membranes, piping, and basic finishes [29]. Inferring the above and as a conditioning principle of the proposal, it is proposed not to modify the modulation or squareness of the structure or the characteristics of the complementary construction elements. Therefore, the proposal will address three aspects: thermal envelope, ventilation and orientation. The thermal envelope has defined as the perimeter elements of buildings that separate them from the outside environment, either from a contiguous open space or an unconditioned space [30]. According to the thermal transmittance analysis and under the premise of not modifying the section of the timber structural elements. It proposed to increase the thermal insulation, exclusively in the roof, since the height of the beam allows it, but not the sections of the right foot of the exterior walls.

In addition, it has suggested that a water-repellent membrane be incorporated throughout the envelope to act as a moisture and wind barrier, which has not considered in the initial module (Figure 16). The second dimension to be reformed corresponds to ventilation, which has understood as the change of a portion of air that is considered undesirable for another of better quality, which improves its purity, temperature, humidity, etc. [31]. Likewise, it is evident that when designing more thermally protected buildings with lower levels of thermal transmission and more airtight, the solution for ventilation in the building becomes more complex [32]. For this reason, as a passive ventilation strategy, the one given by the height effect will have used the air direction a fundamental factor to has considered. Therefore, for greater comfort through ventilation, the inlet windows should be at the lower part, at the level of the people in the enclosure, and the upper outlet windows will allow the extraction of the warm air deposited in the upper layers of the interior space [31]. The module has implemented replicating the exterior facing towards the interior, preserving its two windows or replacing one with a door opening to access the enclosure. In addition to this, it recommended placing the sash windows opening downwards so that the space for ventilation is in the upper part of the wall, thus promoting the strategy of ventilation by height. Likewise, for this strategy to be effective, the interior corridor, from where the enclosures are accessed, should raise its roof to evacuate the hot air through the proposed upper windows, as shown in (Figures 17-19). Complementary, the energy demand for both heating and cooling depends mainly on the orientation of the building enclosures. Therefore, a good orientation could considerably minimize energy demands by controlling solar gains [28].



Figure 16: Roof construction detail.

Source: developed by the authors.

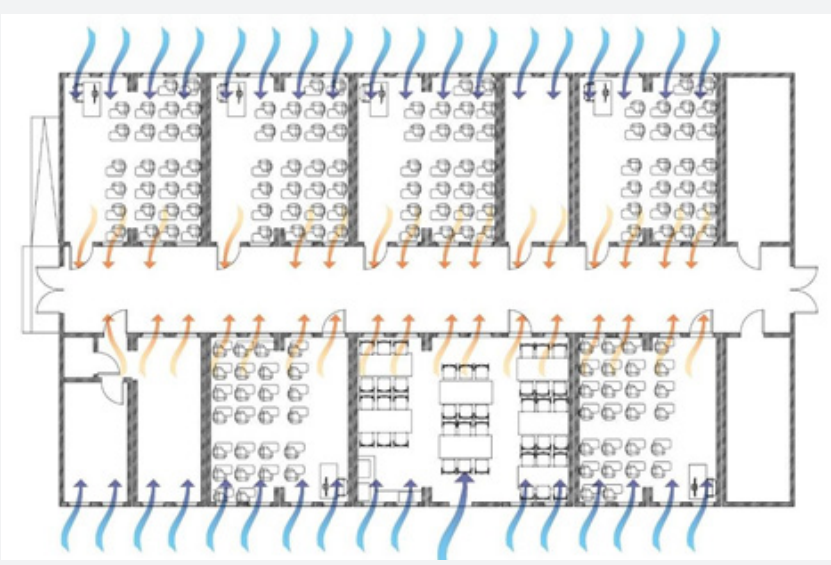

Figure 17: Scheme of Ventilated classroom.

Source: developed by the authors. 


\section{Civil Engineering Research Journal}

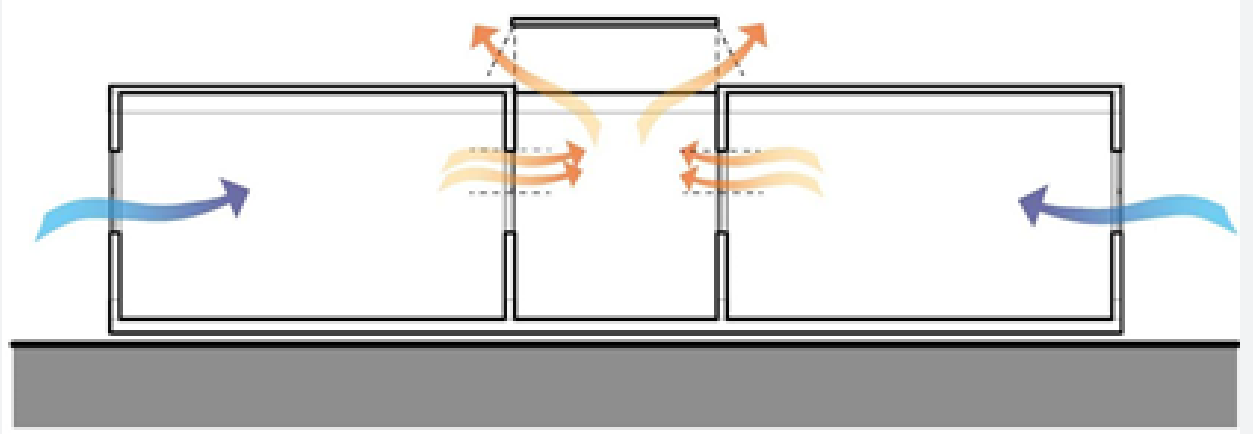

Figure 18: Scheme of Ventilated classroom.

Source: developed by the authors.

Figure 19: Scheme of Ventilated classroom.

Source: developed by the authors.

A north façade receives solar radiation during most of the day depending on the latitude and the time of year. In winter, the sun is lower concerning the zenith to have a greater penetration through glazed surfaces. This facade has shaded in summer with horizontal shading such as eaves. (Passive Design Manual, p.22). Eaves are not included in the proposal but can be considered external elements superimposed on the module, as was proposed with the covered walkway structure. On the other hand, the southern facade does not receive direct solar radiation during most of the year. Only in summer it may receive some sun; depending on the latitude; it does not require solar protection. [33] However, depending on the climate in which the project location, the glazed surfaces of this façade must achieve an adequate balance to avoid excessive heat loss and achieve good natural lighting. [28].

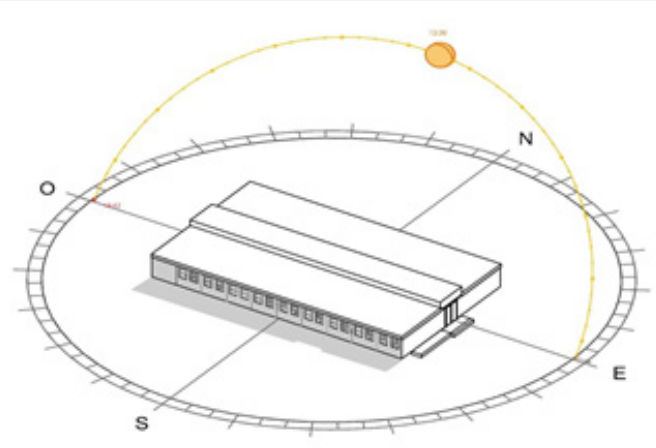

Figure 20: Scheme of the orientation of the school modules to North-South.

Source: developed by the authors.

Therefore, we proposed to change the orientation of the school modules to North-South, as shown in (Figure 20). Finally, the proposal seeks to improve the base case to allow this modular construction installation in more climatic zones from the thermal 
envelope's adaptability and correct significant deficiencies that affect indoor air quality in classrooms. In this way, its adaptation to different climates (variable 1.1) and its habitability optimized by improving its passive strategies and natural ventilation system (variables 2.1, 2.2, 2.3 and 2.4), all without structurally modifying the base module (Table 13). In this way, the base module increases its applicability from 3 to 6 climatic zones (yield 66\%). In summary, the aim is to increase the habitability and, therefore, the durability of the modular school solution, maximizing improvements, but without modifying the layout of Tecnofast, the industrializing factory. In this way, the company will not have to incur significant investments to better future school projects.

Table 13: Comparative table of improvement results for the nine climatic zones of Chile.

\begin{tabular}{|c|c|c|c|c|c|c|c|c|c|c|c|}
\hline \multirow[t]{2}{*}{ Variable } & $\begin{array}{c}\text { Iloca } \\
\text { School } \\
\end{array}$ & $\begin{array}{c}\text { Zone } \\
\text { 4CL }\end{array}$ & $\begin{array}{l}\text { Zone } \\
\text { 1NL }\end{array}$ & $\begin{array}{l}\text { Zone } \\
\text { 2ND }\end{array}$ & $\begin{array}{l}\text { Zone } \\
\text { 3NVT }\end{array}$ & $\begin{array}{l}\text { Zone } \\
5 \text { CL }\end{array}$ & $\begin{array}{l}\text { Zone } \\
\text { 6SL }\end{array}$ & $\begin{array}{l}\text { Zone } \\
\text { 8SE }\end{array}$ & $\begin{array}{c}\text { Zone } \\
\text { 7SI }\end{array}$ & $\begin{array}{l}\text { Zone } \\
\text { 9AN }\end{array}$ & \multirow[t]{2}{*}{ Compilance } \\
\hline & \multicolumn{10}{|c|}{$\mathrm{U}$ value $\mathrm{w}\left(\mathrm{m}^{2} \mathrm{k}\right)$} & \\
\hline $\begin{array}{l}\text { Roof limit trans- } \\
\text { mittance }\end{array}$ & 0,33 & 0,6 & 0,8 & 0,4 & 0,6 & 0,4 & 0,4 & 0,3 & 0,25 & 0,25 & \multirow{3}{*}{$66 \%$} \\
\hline $\begin{array}{l}\text { Wall limit trans- } \\
\text { mittance }\end{array}$ & 0,48 & 0,8 & 2 & 0,5 & 0,8 & 0,6 & 0,6 & 0,5 & 0,4 & 0,3 & \\
\hline $\begin{array}{l}\text { Ventilated floor } \\
\text { limit transmit- } \\
\text { tance }\end{array}$ & 0,39 & 1,2 & 3 & 0,7 & 1,2 & 0,8 & 0,8 & 0,7 & 0,5 & 0,4 & \\
\hline
\end{tabular}

Source: developed by the authors.

\section{Conclusion}

First, the base module responds thermally to 3 climatic zones in Chile. Zone 4 Central Litoral, Zone 1 Norte Litoral and Zone 3 Norte Valle Transversal. (33\% performance) but presents deficiencies in the quality of the indoor air in the classrooms. The prototype allows generic adaptations that increase the habitability of the classroom in different climatic zones, making it more efficient. The new comfort in habitability contributes to a significant advance as a response method for critical infrastructure. To increase adaptability from an environmental design approach and the lowest economic cost means increasing resilience. It also strengthens the paradigm shift of moving from emergencies towards a permanent solution where modular architecture can be thought from the concept of resilience and expansion projection, contributing to a built back better approach in disaster risk reduction strategy.

\section{References}

1. Lara A, Reyes LF, Moreno J, Quilodrán P, Sánchez K (2018) Designing happiness? A close-up to the housing reconstruction process after the Chile earthquake and tsunami on February 27, 2010. Natural Hazards 91(2): 537-551.

2. UNDRR/GETI; UNOSSC \& PAHO (2020) Making Cities Resilient: Developing and Implementing Local Disaster Risk Reduction Strategy to Respond to COVID-19 and better prepare for the future.

3. Seeliger L, Turok I (2016) Towards Sustainable Cities: Extending Resilience with Insights from Vulnerability and Transition Theory. In Ecological Resilience: Response to Climate Change and Natural Disasters p. 39-68.

4. Tolulope B, Mukalazi A, Ropo I (2019) Spatial planning and climate change adaptation assessment: Perspectives from Mdantsane Township dwellers in South Africa. Habitat International 90: 1-9.

5. Lara A (2016) Higher education in Latin America and the Caribbean for management and Disaster Risk Reduction. Are we preparing our population? Journal of Studies and Experience in Education REXE 15
(29): 49-63.

6. Villagra P, Herrmann G, Quintana C, Sepúlveda RD (2016) Resilient thinking and urban planning in a coastal environment under tsunami risk: the case of Mehuín, Chile. Journal of Northern Geography 62(64): 55-62.

7. Lloyd, MG, Peel D (2006) City Regionalism and City Regions in Scotland? In Tewdwr-Jones M, Allmendinger P (Eds.), Territory, Identity and Spatial Planning pp. 285-304.

8. UN (2015) Sendai Framework for Disaster Risk Reduction 2015-2030. Third UN World Conference on Disaster Risk Reduction in Sendai, Japan.

9. (2013) Ministry of Education Reconstruction in education. A look at the processes and challenges in the reconstruction of the school infrastructure damaged in the earthquake and tsunami of $27 / \mathrm{F}$. MINEDUC, Government of Chile.

10. IPCC (2014) Climate Change 2014: Synthesis Report. Contribution of Working Groups I, II and III to the Fifth Assessment Report of the Intergovernmental Panel on Climate Change. In: Pachauri RK, Meyer LA (Eds), IPCC, Geneva, Switzerland, pp. 151.

11. Polo Díaz H (2016) A Conceptual Framework for Understanding Vulnerabilities to Extreme Climate Events. In: Leal Filho W (Eds.), Climate Change, Adaptation, Resilience and Hazards, pp. 143-156.

12. Roggema R Towards (2016) Enhanced Resilience in City Design: A Proposition. In Ecological Resilience: Response to Climate Change and Natural Disasters, Apple Academic Press, pp. 167-196.

13. (2014) Ministry of Interior Reconstruction status diagnosis, earthquake and tsunami 27f. Presidential Delegation for the Reconstruction Government of Chile.

14. Educa UC (2014) Child and Youth Welfare Survey Report in educational establishments. Pontifical Catholic University of Chile. Santiago, Chile.

15. Jirón M, Paola Toro B, Alejandro Caquimbo S, Sandra Goldsack J, Luis, et al. (2004) Housing well-being. Design guide for a sustainable residential habitat. Santiago, Chile, Faculty of Architecture and Urbanism, University of Chile; Federico Santa María Technical University, and Technological Development Corporation, Housing Institute, Faculty of Architecture and Urbanism, University of Chile, p. 113. 


\section{Civil Engineering Research Journal}

16. Cubillos R, Trujillo J, Cortés O, Rodríguez C, Villar M (2014) Habitability as a variable in the design of buildings aimed at sustainability. Architecture Magazine 16(1): 114-125.

17. Connelly RI, Bar P (2016) Local Networks of Resilience and Climate Adaptation: The Case of Istanbul. In Leal Filho W (Edt.), Climate Change, Adaptation, Resilience and Hazards, pp: 109-123.

18. Kotnik J (2014) New container architecture: design guide +30 case studies, ( $1^{\text {st }}$ edn.), links books.

19. Stelliano C (2004) Construction in the fast line. Florida, USA

20. Molina C (2014) Innovation in the design of modular homes through the use of containers. Thesis to qualify for the Title of Construction Engineer, Austral University of Chile.

21. Erwood D (2013) A modular Space. California, USA.

22. Masys A (2015) Disaster Management: Enabling Resilience. Springer.

23. Aravena A (2015) Elemental: architecture as strategy. Area: magazine of architecture and design arts 143: 2-17

24. Cubillos R, Novegil F, Cortés O (2017) Resilient and efficient territories in Bogotá. Bogotá: Catholic University of Colombia, USA.

25. (2012) UC Public Policy Center. Emergency and reconstruction, before and after the earthquake and tsunami of $27 \mathrm{~F}$ in Chile, learning about housing, urban and insurance matters. Pontifical Catholic University of Chile, p. 39-49.

26. Suprem Decree 548. (1989) Approves standards for the physical plant of educational premises that establish the minimum requirements that establishments recognized as cooperators of the educational function of the state must meet, according to the level and modality of the education they impart. Ministry Of Public Education-Santiago de Chile.

27. Miranda N (2015) Architecture for humanitarian emergencies, Transitory solutions that facilitate the reconstruction process. Faculty of Architecture and Urbanism, University of Chile.

28. (2011) Ministery of Public Works (TDRe MOP). Standardized terms of reference with parameters of energy efficiency and environmental

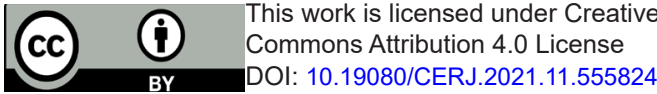

comfort, for Design and Work Bids. Santiago, Chile: Ministry of Public Works. Government of Chile.

29. Zilic F, Ortega P, Torres V (2019) Industrialization manual. Concepción, Chile: Editions University of Concepción.

30. (2016) Ministry of housing and urbanism. Technical standards for residential buildings. Santiago, Chile: Ministry of Housing and Urbanism. Government of Chile.

31. Bustamante, Waldo (2009) Design Guide for the energy efficiency of social housing. Stgo de Chile, Ministry of Housing and Urbanism, (Series II Construction Technology), p. 74.

32. González Cáceres A, Fritz Durán A, Bobadilla Moreno A, Recart Zapata C, Muñoz Viveros C, et al. (2014) Manual of air tightness of buildings. Concepción, Chile: Editions Universidad del Bío-Bío, Chile.

33. (2012) Research Center in Construction Technologies, U. D. B. B. Design, Passive and Energy Efficiency Manual in Public Buildings. Santiago, Chile: Institute of Construction.

34. Karunasena G, Amaratunga D (2016) Capacity building for postdisaster construction and demolition waste management. A case of Sri Lanka. Disaster Prevention and Management 25(2): 137-153.

35.https://reliefweb.int/sites/reliefweb.int/files/resources / Diagnostico \%20Estado\%20 de \%20la\%20 Reconstruccion Terremoto\%20y\%20tsunami\%202010.pdf

36. NCh 853 (2007) Chilean Standard Thermal conditioning - Thermal envelope of buildings - Calculation of resistance and thermal transmittance. National Institute of Normalization.

37. NCh 1079 (2008) Chilean Standard for Housing Climate Zoning for Chile and recommendations for architectural design. Ministry of Housing and Urbanism, Government of Chile.

38. (2012) Plataforma arquitectura Modular Illoca School installation process.

\section{Your next submission with Juniper Publishers will reach you the below assets}

- Quality Editorial service

- Swift Peer Review

- Reprints availability

- E-prints Service

- Manuscript Podcast for convenient understanding

- Global attainment for your research

- Manuscript accessibility in different formats

( Pdf, E-pub, Full Text, Audio)

- Unceasing customer service

Track the below URL for one-step submission https://juniperpublishers.com/online-submission.php 